\title{
Mental Health Education
}

\author{
C. I. Röscher \\ Chief Nursing Officer, Department of Health
}

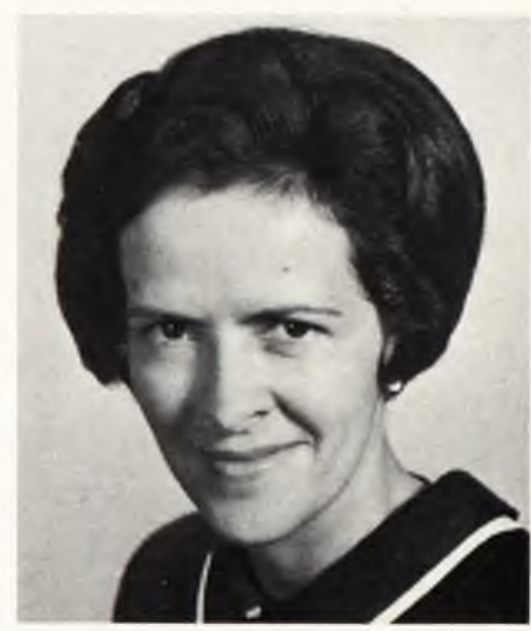

\section{OPSOMMING}

Die doel van geestesgesondheid vandag strek verder as 'n verligting van geestesongesteldheid. Die dae van sorg onder toesig in inrigtings wat van die gemeenskap afgeskei is, hoort in geskiedenisboeke tuis. Ons moet selfs verder kyk as die behandeling of voorkoming van geestesongesteldheid na die ideaal van maksimale fisiese, geestes- en maatskaplike doeltreffendheid t.o.v. die individu, sy gesin en die gemeenskap. Geestesgesondheidsvoorligting is 'n gedragswetenskap wat daarop mik om gedrag en houdings te verander wat teen die bereiking van die ideale indruis.

$\mathbf{T}$ HE goal of mental health today calls for more than an alleviation of mental illness. The days of custodial care in institutions, segregated from the community, belong in the history books. We must look even further than the treatment or even the prevention of mental illness to the ideal of maximum physical, mental and social efficiency for the individual, his family and the community. Mental Health Education is a behavioural science which aims to change behaviour and attitudes which militate against the achievement of these goals.

The vast field of mental health is beset with prejudice, ignorance and fears. For this reason it is essential to provide more than mere information regarding mental illness. The community must be motivated to act on the information given and be prepared to try to counteract the pressures which are inimical to mental health.

With these ideas in mind it is easy to see that those working in the field of mental health education need rare qualities of sensitivity and tact. A real sense of commitment and caring and a balanced and mature approach are vital if deep-rooted fears and prejudices are to be eradicated. All the technical knowledge and equipment will be wasted if the ability to communicate on a warm person-to-person basis is not present. Sir John Stallworthy, President of the British Medical Association has said:
"Failure to recognise the fact of the importance of communication is the basis of much present worldwide trouble in most aspects of modern life, including medicine itself '. '

He summarises this necessity by saying that there must be "someone who cares, a message to give, a desire to receive it, and an acceptable technique of presentation".

Bodenstein takes this a step further when he says:

"Manifold are the barriers of communication which have to be crossed in the course of health education. The one who desires to cross them all, and wants to avoid rebuffs, must make sure that he knows the strategy which is the secret of communication. It is to start at the centre and then move outwards in sequence, crossing from each concentric sphere to the adjacent outer one. To start at the centre simply means that I must start with myself. It is the old question in everybody"s life - and of exceptional weight in equipping us for health education - namely of knowing myself, of becoming so objective about myself that I can see myself through the eyes of others. For it is only he who can as it were communicate with himself, who will make uninterrupted progress in communicating with more and more others, until he crosses, without visible effort, the most distant barriers."'2

Potential which is lying dormant in individuals and groups must be recognised and mobilised to bring about a new way 
of life and a more positive attitude to mental health.

In South Africa with its multi-cultural society the need for sensitivity and respect for cultural norms which differ from those to which we are accustomed, is of great importance. In the field of cross-cultural mental health it is not necessary to accept the values of the group with which one is dealing, but it is essential that they be approached with the utmost respect. These values must be fully understood with insight into their basis and their effects on mental health. The educator must give careful consideration to the extent to which he is justified in leaving these values untouched - if they need changing, why and how should he set about this with the minimum of interference. He should also give thought to whether there is any guarantee that the change will bring about the desired results. This is sensitive and vulnerable ground which demands an uncriticising respect for human dignity at all levels.

The scope of mental health education is indeed vast. Prof. W. D. Pienaar sees psychiatric problems as an expression of family problems. ${ }^{3}$ Ecological factors, he states, are behind the antecedents of family violence. These ecological factors are such things as lack of privacy, high density living, oppressive heat and excessive noise. It is obvious from this that not only the psychiatrist, social worker, nurse and psychologist should be involved in mental health education, but the architect and town planner should also be involved. Each profession has a unique contribution to make. Interdisciplinary co-operation is essential at a professional level but one must never forget that any mental health education cam- paign is doomed to failure unless individuals and groups in the community identify positively with the programme. It is also important that the community takes an increasing initiative - feeling that the programme is their own. It remains essential however that the professional mental health worker retain control.

Nothing of what I have said is new. It has all been said many times. The alarming fact is that so little progress appears to have been made in this vitally important field. As far back as 1954 Levy expressed concern about the lack of mental health education in postnatal and well-baby clinics. ${ }^{4}$ He states that so much attention was given to weight. feed formulas, and physical care, but nurses were never taught to recognise poor mothering. Since the very core of mental health is sound interpersonal relationships the foundations of which are laid in those early years, he saw this as an important area for mental health intervention. How much progress have we made?

\section{BIBLIOGRAPHY}

1. Stallworthy, Sir John. The Harben Lecture, Roval Institute of Public Health and Hygiene, 1975. Community Health (1976), 7. p. 184 et seq

2. Bodenstein J. Wolfgang. The Principles and Role of Health Educarion. Paper delivered at symposium at University of the North. "Health Services for Developing Countries, 1977. Unpublished.

3. Pienaar W. D. (Associate professor of Psychology at the University of Por Elizabeth). Family Violence; an Ecological Approach. Paper delivered at Multi National Conference. TARA the H. Moross Centre. 1972

4. Levy D. M. American Journal of Public Health 1954. Vol. 44 page 1113 